\title{
Rooting of semi-hardwood stem cuttings from current year shoots of Drymis brasiliensis
}

\author{
Enraizamento de estacas caulinares semilenhosas de \\ Drimys brasiliensis oriundas de brotação do ano \\ Luciele Milani Zem ${ }^{\mathrm{I}}$ Katia Christina Zuffellato-Ribas ${ }^{\mathrm{II}}$ \\ Maria Izabel Radomski ${ }^{I I I}$ Henrique Soares Koehler ${ }^{\text {IV }}$
}

\section{ABSTRACT}

Drimys brasiliensis Miers is an Angiosperm native to the Atlantic Rainforest, commonly known as cataia. Because of dormancy of its seeds, due to embryonic immaturity, production of cataia seedlings presents challenges regarding propagation of the species. Thus, cuttings emerged as a possible technique to be applied, diminishing plants production time and ensuring uniformity of rooting. Stem cuttings from current year shoots were collected in autumn/2012, prepared with 10-12cm in length, a bevel cut on base and straight on top, keeping two leaves, one leaf or no leaves in the apical portion. After disinfestation, bases of cuttings were submitted to the following treatments with indole-3-butyric acid (IBA) in 50\% hydro-alcoholic solution: 100\% water, 0, 500, 1500, 3000, 4500 and $6000 \mathrm{mg} L^{-1}$ IBA. A completely randomized experimental design was used, with 3 types of cutting $x 7$ IBA concentrations, with four replicates of 10 cuttings per experimental unit. After 120 days, the variables percentage of rooted cuttings, number of roots per cutting, length of the three longest roots per cutting, percentage of cuttings with callus, alive and dead, with new shoots and the cuttings maintaining the original leaves were assessed. The application of IBA had no influence on any of the assessed variables. Cuttings with two leaves presented the best rooting percentage (51.1\%) and the lowest mortality (5.4\%), when compared to cuttings with one leaf $(35.0 \%)$ or without leaves (0.4\%). Cuttings without leaves are to be avoided, since they present the highest mortality percentage (93.6\%).

Key words: Winteraceae, Cataia, indole-3-butyric acid, cuttings.

RESUMO

Drimys brasiliensis Miers é uma Angiosperma nativa da Mata Atlântica conhecida popularmente como cataia. Por apresentar dormência em suas sementes devido à imaturidade embrionária, a produção de mudas de cataia apresenta uma problemática a ser desvendada no que se refere à propagação da espécie. Assim, a estaquia foi utilizada como uma possível técnica a ser utilizada, diminuindo o tempo de obtenção das mudas e possibilitando a uniformidade de enraizamento. Estacas caulinares provenientes de brotações do ano foram coletadas no outono/2012, confeccionadas com $10-12 \mathrm{~cm}$ de comprimento, corte em bisel na base e reto no ápice, mantendo-as com duas, uma e sem folhas na porção apical. Após desinfestação, as bases das estacas foram submetidas aos seguintes tratamentos com ácido indol butírico (IBA) em solução hidroalcoólica 50\%: 100\% água, 0, 500, 1500, 3000, 4500 e 6000mg L L IBA. Foi utilizado um delineamento inteiramente casualizado, com 3 tipos de estacas $x 7$ concentrações de IBA, com quatro repetições contendo 10 estacas por unidade experimental. Após 120 dias, avaliou-se a porcentagem de estacas enraizadas, número de raizes por estaca, comprimento das três maiores raizes por estaca, porcentagem de estacas com calos, vivas, mortas, com novas brotações e que mantiveram suas folhas originais. A aplicação de IBA não influenciou nenhuma das variáveis estudadas. Estacas com duas folhas apresentaram melhor enraizamento (51,1\%) e menor porcentagem de mortalidade $(5,4 \%)$, quando comparadas com estacas com uma folha (35,0\%) ou sem folhas (0,4\%). A estaquia sem a presença de folhas não é recomendada, por causar a maior porcentagem de mortalidade $(93,6 \%)$.

Palavras-chave: Winteraceae, Cataia, ácido indol butírico, estaquia.

\section{INTRODUCTION}

Drimys brasiliensis Miers, commonly known as cataia, is an angiosperm native to the Atlantic Rainforest, belonging to the Winteraceae

\footnotetext{
IUniversidade Federal do Paraná (UFPR), Rua Quintino Bocaiúva, 105, 80035-090, Curitiba, PR, Brasil. E-mail: luzem@uol.com.br. Corresponding author.

IIDepartamento de Botânica, Universidade Federal do Paraná (UFPR), Curitiba, PR, Brasil.

IIIEmbrapa Florestas, Colombo, PR, Brasil.

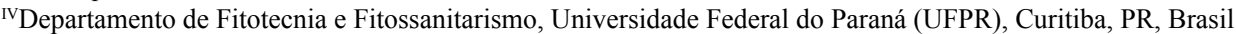
Received 10.07.14 Approved 07.14.16 Returned by the author 09.30.16 CR-2014-1486.R2 
family, order of Canellales (CRONQUIST, 1981; TRINTA \& SANTOS, 1997). According to SCHEIDT et al. (2002), species of the genus Drymis are characterized by the use of their bark in the traditional Brazilian medicine as stimulants, antispasmodic, aromatics, antidiarrheal, antipyretic, against uterus hemorrhage and in some affections of the digestive tract (SIMÕES et al., 1986).

Cataia seeds present dormancy, which is a problem for seed analysis and production of seedlings. Dormancy is due to embryonic immaturity, because embryos are rudimental and need an additional time period to complete their development before being ready to germinate (ABREU et al., 2005). Due to difficulties in production of plants by seeds, vegetative propagation is a good alternative, in order to achieve large-scale production, reduce production time and obtain rooting uniformity (HARTMANN et al., 2011).

Presence of leaves in cuttings preparation may have an important role in rooting induction, because leaves are the production center of hormones and photoassimilates in great quantities elements necessary for rhizogenesis (ALVARENGA \& CARVALHO, 1983; HARTMANN et al., 2011).

Application of plant growth regulators belonging to auxins group, on the bases of cuttings, has the objective to stimulate growth of roots, propitiate increase of rooted cuttings percentage, reducing time of roots formation and permanence time in rooting bed (ALVARENGA \& CARVALHO, 1983).

This research aimed to evaluate the effect of different indole-3-butyric acid (IBA) concentrations on rooting of semi-hardwood stem cuttings from current year shoots of Drimys brasiliensis, prepared with two leaves, one leaf and no leaves on the apical portion.

\section{MATERIALS AND METHODS}

Vegetative material of Drimys brasiliensis Miers was collected in woods property of Embrapa Florestas, Colombo - PR, coordinates 2519'16" south and $49^{\circ} 09^{\prime} 31^{\prime \prime}$ west. According to Köppen classification, climate of the region is Cfb type, characterized as humid temperate with average temperature of the hottest month above $10^{\circ} \mathrm{C}$, with mild summers and winters with frequent frost, tendency of rainfall concentrations in summer; although, without a defined dry season.

Branches from 16 stock plants, at the age of five years, were collected on April 2, 2012, corresponding to the autumn season. Starting from those branches, semi-hardwood stem cuttings were prepared,
$10-12 \mathrm{~cm}$ in length, a straight cut on top and bevel cut on base, in three different types defined as with two leaves, one leaf or no leaves on the apical portion.

Then, they were submitted to disinfestation in sodium hypochlorite $0.5 \%$ solution for 10 minutes and were subsequently washed in running water for five minutes. Later, they were treated for five minutes with Derosal ${ }^{\circledR} 500 \mathrm{SC}$ fungicide, whose active ingredient is carbendazim, at a dosage of $1 \mathrm{ml} \mathrm{L}^{-1}$.

Bases of cuttings were treated with different indole- 3 butyric acid (IBA) concentrations, in $50 \%$ hydroalcoholic solution, for 10 seconds immersion, according to the following treatments: control (100\% water), $0 \mathrm{mg} \mathrm{L}^{-1} \mathrm{IBA}, 500 \mathrm{mg} \mathrm{L}^{-1}$ IBA, $1500 \mathrm{mg} \mathrm{L}^{-1}$ IBA, 3000 $\mathrm{mg} \mathrm{L}^{-1}$ IBA, 4500mg $\mathrm{L}^{-1}$ IBA and $6000 \mathrm{mg} \mathrm{L}^{-1}$ IBA. Plantation took place in $53 \mathrm{~cm}^{3}$ volume polypropylene pots, containing moistened mixture of fine grain vermiculite and carbonized rice hull $(1: 1)$.

The experiment was installed following a completely randomized design with factorial arrangement $3 \times 7$ (3 types of cuttings $\times 7$ IBA concentrations), with four replicates of 10 cuttings per experimental unit, totalizing 280 cuttings per type.

After 120 days from installation of the experiment, conducted in temperature controlled greenhouse with intermittent misting (relative humidity $80 \%$ and temperature between 20 and $30^{\circ} \mathrm{C}$ ), the following variables were evaluated: percentage of rooted cuttings (alive cuttings with at least $1 \mathrm{~mm}$ long roots, with or without callus); number of roots per cutting; length of the three longest roots per cutting $(\mathrm{cm})$, cuttings with callus (alive, without roots, with formation of undifferentiated cellular mass); alive cuttings (alive, without roots or callus), dead cuttings (presenting necrotic tissues), cuttings with shoots (presenting new shoots in the apical portion) and cuttings that maintained the original leaves.

Variances of treatments had homogeneity tested by the Bartlett's test. Variables, whose treatments effect variances showed homogeneity, were submitted to analysis of variance and, if significant differences by the $\mathrm{F}$ test emerged, had their means compared by the Tukey range test at $5 \%$ of probability. None of the treatments variances showed to be heterogeneous.

\section{RESULTS AND DISCUSSION}

There was no interaction between the analyzed factors, indicating that they are independent, for the following variables: rooting percentage, average number of roots per cutting, average length of roots 
per cutting, percentage of alive, dead and cuttings that maintained their original leaves. There was interaction for the variable percentage of cuttings with callus and with shoots, indicating that these factors are not independent. There was significant difference at $1 \%$ of probability in all variables for the types of cuttings (Table 1). There was significant difference at $1 \%$ level of probability in the variable percentage of cuttings with callus for the different IBA concentrations (Table 2).

In the experiment conducted comparing types of cuttings, all variables gave significant difference. Cuttings with two leaves showed best rooting $(51.07 \%)$ and lowest dead cuttings percentage $(5.35 \%)$, when compared to cuttings with one or no leaves (Table 1). Low rooting was observed in cuttings without leaves $(0.35 \%)$, showing that presence and maintenance of leaves throughout the rooting process is an important factor for adventitious roots induction, growth and development. The fact that cuttings prepared with two leaves presented better rooting when compared to the ones with one leaf is probably due to higher photoassimilates and auxins production where biggest leaf surface was available (NIENOW et al., 2010). Studying acerola tree cuttings (Malpighia punctifolia), GONTIJO et al. (2003) verified that the presence of two pairs of leaves returned best rooting percentage, while cuttings without leaves showed no rooting at all. BIASI et al. (1997) also observed lack of root formation in cuttings without leaves of Vitis vinifera, confirming the great importance of leaves for the rooting process to semi hard wood cuttings.

MINDÊLLO NETO (2006), studying herbaceous cuttings of Prunus persica, observed insignificant or total lack of rooting when leaves were not present; however, when two leaves were kept on cuttings, average rooting percentage reached $40 \%$. In this research, roots development was influenced by the type of cutting, because cuttings prepared with two leaves presented greatest number of roots and average length of the three longest roots per cutting $(2.15$ and $0.53 \mathrm{~cm})$, while cuttings with no leaves showed no root formation at all (Table 1). Thus, it is clear that presence of leaves was fundamental to stimulate growth of roots, as already observed in Lippia alba by LOLLI (2001).

Mainly for species whose rooting is difficult, presence of leaves is stimulating to formation of roots (PAGEL, 2004; HARTMANN et al., 2011). According to BIASI (2002), presence of leaves and active gems are important factors to stimulate rhizogenesis.

Just as the presence of leaves, application of indole-3-butyric acid (IBA) has positive influence on rooting, as observed by various authors (BORTOLINI et al., 2008; LANA et al., 2008). External applications of plant growth regulators, mainly of the auxins group, results in greater rooting percentage, velocity and development, although recommended concentrations may differ depending on species, maturation, environmental conditions and application method (HARTMANN et al., 2011). However, results obtained in this research did not confirm the positive effect of IBA for Drimys brasiliensis Miers.

Besides auxins, adventitious roots formation is due to transportable metabolites, including nutritional and hormonal substances, together with specific rooting co-factors (RIBAS, 1997). Presence of leaves is necessary to production of auxins, which are transported to the base of cuttings, contributing to morphogenetic process of new tissues formation, including roots (HARTMANN et al., 2011).

In $\boldsymbol{D}$. brasiliensis, considering the variable percentage of alive cuttings (alive cuttings with no roots), there was greatest survival in cuttings with one leaf, when compared to cuttings with two or with no leaves (respectively 15.71\%, 7.14\% and $6.07 \%$ ) (Table 1). This is because cuttings with lower leaf surface generally have less water loss by transpiration; thus less dehydration, besides the

Table 1 - Comparison of means for variables of Drimys brasiliensis Miers cuttings: rooted (RC), number of roots per cutting (NR), average length of roots (ALR), alive (AC), dead (DC) and with maintained leaves (MLC), with two, one and no leaves, Curitiba, PR, 2012.

\begin{tabular}{|c|c|c|c|c|c|c|}
\hline \multirow{2}{*}{ Type of cutting } & $\mathrm{RC}$ & NR & ALR & $\mathrm{AC}$ & $\mathrm{DC}$ & MLC \\
\hline & $\%$ & & $\mathrm{~cm}$ & $\%$ & $\%$ & $\%$ \\
\hline 2 Leaves & $51.07 \mathrm{a}$ & $2.15 \mathrm{a}$ & $0.53 \mathrm{a}$ & $7.14 \mathrm{~b}$ & $5.35 \mathrm{c}$ & $87.14 \mathrm{a}$ \\
\hline 1 Leaf & $35.00 \mathrm{~b}$ & $1.43 \mathrm{~b}$ & $0.32 \mathrm{~b}$ & $15.71 \mathrm{a}$ & $13.21 \mathrm{~b}$ & $73.57 \mathrm{~b}$ \\
\hline Without leaves & $0.35 \mathrm{c}$ & $0.00 \mathrm{c}$ & $0.00 \mathrm{c}$ & $6.07 \mathrm{~b}$ & $93.57 \mathrm{a}$ & - \\
\hline Coefficient of variation $(\%)$ & 50.69 & 79.95 & 72.05 & 103.91 & 25.78 & 25.60 \\
\hline
\end{tabular}

Means followed by the same letter in the column are not statistically different at $5 \%$ level of significance. 
Table 2 - Comparison of interaction means of the variable cuttings with callus of Drimys brasiliensis Miers between type of cutting and IBA concentrations factors, Curitiba, PR, 2012

\begin{tabular}{|c|c|c|c|c|c|c|c|c|c|}
\hline \multirow{2}{*}{$\begin{array}{l}\text { Treatments } \\
\text { Water }(100 \%)\end{array}$} & \multicolumn{3}{|c|}{2 Leaves } & \multicolumn{3}{|c|}{1 Leaf } & \multicolumn{3}{|c|}{ Without leaves } \\
\hline & 35.00 & $\mathrm{a}$ & $\mathrm{A}$ & 37.50 & $\mathrm{a}$ & $\mathrm{A}$ & 0.00 & $\mathrm{a}$ & $\mathrm{B}$ \\
\hline water + alcohol & 42.50 & $\mathrm{a}$ & A & 30.00 & $\mathrm{a}$ & A & 0.00 & $\mathrm{a}$ & B \\
\hline $500 \mathrm{mg} \mathrm{L}^{-1} \mathrm{IBA}$ & 35.00 & a & A & 32.50 & $\mathrm{a}$ & A & 0.00 & $\mathrm{a}$ & B \\
\hline $1500 \mathrm{mg} \mathrm{L}^{-1} \mathrm{IBA}$ & 32.50 & $\mathrm{a}$ & A & 45.00 & $\mathrm{a}$ & A & 0.00 & $\mathrm{a}$ & B \\
\hline $3000 \mathrm{mg} \mathrm{L}^{-1} \mathrm{IBA}$ & 30.00 & $\mathrm{a}$ & A & 40.00 & $\mathrm{a}$ & A & 0.00 & $\mathrm{a}$ & B \\
\hline $4500 \mathrm{mg} \mathrm{L}^{-1} \mathrm{IBA}$ & 40.00 & a & A & 37.50 & $\mathrm{a}$ & A & 0.00 & $\mathrm{a}$ & B \\
\hline $6000 \mathrm{mg} \mathrm{L}^{-1} \mathrm{IBA}$ & 37.50 & a & A & 32.50 & $\mathrm{a}$ & A & 0.00 & $\mathrm{a}$ & B \\
\hline Coefficient of Variation (\%) & \multicolumn{9}{|c|}{65.17} \\
\hline
\end{tabular}

Means followed by the same letter in columns (lower case), and in lines (upper case) are not statistically different at $5 \%$ level of significance.

good development of cuttings that maintained leafs and thus should have conserved their photosynthetic capability, synthesizing organic components used for roots formation (HARTMANN et al., 2011).

Presence of leaves in cuttings can ensure their survival, both for carbohydrates synthesis through photosynthesis and for auxins and co-factors provision to the rhizogenesis process, stimulating cambium activity and cellular differentiation (LIONAKIS, 1981).

Cuttings without leaves were not viable for $\boldsymbol{D}$. brasiliensis, since mortality percentage in this case was $93.57 \%$ (Table 1). After 90 days from the installation of the experiment, half of the cuttings were already dead; thus, underlining the importance of leaves in survival and rooting throughout the entire process. Just as results in this research, KNAPIK et al. (2003) observed that in Tibouchina pulchra, only cuttings that maintained the original two leaves produced roots, while a significant loss of leaves during the greenhouse period resulted in absence of rooting.

Various authors observed the positive influence of leaves in different species, like PIO et al. (2004) with Ficus carica herbaceous cuttings and MINDÊLLO NETO (2006) with peach tree cv. Charme (Prunus persica). XAVIER et al. (2003) verified $37.50 \%$ rooting in cuttings without leaves of Cedrela fissilis, and from $75 \%$ to $100 \%$ when leaves were maintained. FOCHESATO et al. (2006), similarly to the results of this research studying cuttings of Laurus nobilis L., reported $100 \%$ of dead cuttings in case of no leaves, and from $11.50 \%$ to $16.70 \%$ with leaves. Authors assumed that mortality was due to depletion of reserves caused by new shoots formation and reduction of hormones provided by leaves.

There was no significant difference, for any of the studied variables, when treatments with different IBA concentrations were compared, except for cuttings with callus (Table 2). Application of IBA was not propitious to support rhizogenesis and number of roots per cutting; thus, its use in the described concentrations is not efficient. Corroborating this information, RUFINI et al. (2002) observed the same behavior in Passiflora alata cuttings, just as NIENOW et al. (2010), who concluded that application of indole-3-butyric acid is avoidable to induce rooting of Tibouchina sellowiana cuttings.

When cuttings are treated for rooting induction, they usually form callus, which then turns into roots. However, formation of adventitious roots and callus are independent processes and their simultaneous appearance is due to the cellular division process that takes place in both cases, which can depend on internal and environmental favorable conditions (ALVARENGA \& CARVALHO, 1983; HARTMANN et al., 2011).

Percentage of cuttings with callus was the variable that did not show significant difference between treatments for cuttings with two leaves, one leaf or no leaves. However, comparing different types of cuttings, in all treatments, emerged that cuttings without leaves gave the lowest percentage of callus formations (Table 2).

LEANDRO \& YUYAMA (2008), studying cuttings with complete leaves, half leaf and without leaves of Couepia edulis, had similar results using $0 \mathrm{mg} \mathrm{L}^{-1}, 3000 \mathrm{mg} \mathrm{L}^{-1}$ and $6000 \mathrm{mg} \mathrm{L}^{-1}$ IBA, obtaining greater callus formations in cuttings with complete leaves and half leaf, in all treatments.

Variable percentage of cuttings with shoots showed no significant difference between treatments for cuttings prepared with one leaf and without leaves. However, in cuttings with two leaves, hidroalcoholic solution (50\% water and 50\% alcohol) showed difference only when compared to $3000 \mathrm{mg}$ $\mathrm{L}^{-1}$ IBA treatment (Table 3). 
Table 3 - Comparison of interaction means of the variable cuttings with shoots of Drimys brasiliensis Miers, between types of cutting and IBA concentrations factors, Curitiba, PR, 2012

\begin{tabular}{|c|c|c|c|c|c|c|c|c|c|}
\hline Treatments & \multicolumn{3}{|c|}{2 Leaves } & \multicolumn{3}{|c|}{1 Leaf } & \multicolumn{3}{|c|}{ Without leaves } \\
\hline Water $(100 \%)$ & 37.50 & $a b$ & $\mathrm{~A}$ & 57.50 & $\mathrm{a}$ & $\mathrm{A}$ & 3.00 & $\mathrm{a}$ & $\mathrm{B}$ \\
\hline water + alcohol & 65.00 & $\mathrm{a}$ & A & 42.50 & $\mathrm{a}$ & B & 3.00 & $\mathrm{a}$ & $\mathrm{C}$ \\
\hline $500 \mathrm{mg} \mathrm{L}^{-1} \mathrm{IBA}$ & 52.50 & $a b$ & $\mathrm{~A}$ & 35.00 & a & A & 7.50 & $\mathrm{a}$ & B \\
\hline $1500 \mathrm{mg} \mathrm{L}^{-1} \mathrm{IBA}$ & 45.00 & $a b$ & $\mathrm{~A}$ & 45.00 & $\mathrm{a}$ & A & 8.00 & $\mathrm{a}$ & B \\
\hline $3000 \mathrm{mg} \mathrm{L}^{-1} \mathrm{IBA}$ & 35.00 & $\mathrm{~b}$ & $\mathrm{~B}$ & 57.50 & $\mathrm{a}$ & A & 7.50 & $\mathrm{a}$ & $\mathrm{C}$ \\
\hline $4500 \mathrm{mg} \mathrm{L}^{-1} \mathrm{IBA}$ & 45.00 & $a b$ & $\mathrm{~A}$ & 55.00 & $\mathrm{a}$ & A & 12.50 & $\mathrm{a}$ & B \\
\hline $6000 \mathrm{mg} \mathrm{L}^{-1} \mathrm{IBA}$ & 47.50 & $a b$ & $\mathrm{~A}$ & 60.00 & $\mathrm{a}$ & A & 4.50 & $\mathrm{a}$ & B \\
\hline Coefficient of Variation (\%) & \multicolumn{9}{|c|}{37.82} \\
\hline
\end{tabular}

Means followed by the same letter in columns (lower case), and in lines (upper case) are not statistically different at $5 \%$ level of significance.

Cuttings without leaves produced less shoots in all treatments when compared to cuttings with two leaves or one leaf (Table 3). Cuttings with two leaves produced more shoots when compared to one leaf and no leaves, when treated with hidroalcoholic solution $(50 \%$ water and $50 \%$ alcohol). The treatment $3000 \mathrm{mg} \mathrm{L}^{-1}$ IBA resulted in greater percentage of shoots in cuttings prepared with one leaf (Table 3 ).

In cuttings with two leaves, hydroalcoholic solution treatment $(50 \%$ water and $50 \%$ alcohol) was numerically greater than all other treatments, showing significant difference only from $3000 \mathrm{mg} \mathrm{L}^{-1}$ IBA treatment (Table 3).

Sprouting has direct influence on rooting of cuttings (LEÃO, 2003; ROBERTO et al., 2004). Formation of shoots usually accompanies rooting process. However, interruption of rhizogenesis occurs in some species when newly formed shoots appear (HARTMANN et al., 2011). In case of $\boldsymbol{D}$. brasiliensis there was no observed interruption, due to the high rooting percentage accompanied by great sprouting formation in cuttings with two leaves and one leaf.

\section{CONCLUSION}

Given the conditions of this experiment, it is possible to conclude that considering rooting induction of Drimys brasilensis semi-hardwood cuttings, the best results came from cuttings prepared with two leaves, and that application of indole-3butyric acid is not necessary.

\section{REFERENCES}

ABREU, D.C.A. de et al. Morphological characterization of fruits ands seeds of Drimys brasiliensis Miers. - (Winteraceae). Revista Brasileira de Sementes, v.27, n.2, p.67-74, 2005. Available from: <http://dx.doi.org/10.1590/S010131222005000200010>. Accessed: Aug. 17, 2016. doi: 10.1590/ S0101-31222005000200010.

ALVARENGA, L.R., CARVALHO, V.D. Uso de substâncias promotoras de enraizamento de estacas frutíferas. Informe Agropecuário, v.9, n.101, p.47-55, 1983.

BIASI, L.A. et al. Grapevine rootstock propagation by rooting of semihardwood cuttings. Bragantia, v.56, n.2, p.367-376, 1997.

BIASI, L.A. Reguladores de crescimento vegetal. In: WACHOWICZ, C.M.; CARVALHO, R.I.N. Fisiologia vegetal: produção e pós-colheita. Curitiba: Champagnat, 2002. 424p.

BORTOLINI, M.F. et al. Tibouchina sellowiana (Cham.) Cogn.: rooting, anatomy and biochemical analyses in the four seasons. Ciência Florestal, v.18, n.2, p.159-171, 2008. Available from: $<$ http://dx.doi.org/10.5902/19805098454>. Accessed: Aug. 17, 2016. doi: $10.5902 / 19805098454$.

CRONQUIST, A. An integrated system of classification of flowering plants. New York: Columbia University, 1981. 1262p.

FOCHESATO, M.L. et al. Leaf amounts and indolebutyric acid on Laurus nobilis L. cuttings propagation. Revista Brasileira de Plantas Medicinais, v.8, n.3, p.72-77, 2006. Available from: <https://www.researchgate.net/publication/259450920>. Accessed: aug. 17, 2016.

GONTIJO, T.C.A. et al. Rooting of different types of acerola cuttings using indol butyric acid. Revista Brasileira de Fruticultura, v.25, n.2, p.290-296, 2003. Available from: <https://doaj.org/article/b598130d5b644197916bbae6e9a8bde8> Accessed: Aug. 17, 2016.

HARTMANN, H.T. et al. Plant propagation: principles e practices. 8.ed. Boston: Prentice Hall, 2011. 915p. 
KNAPIK, J.G. et al. The influence of harversting season and indolebutyric acid application on cuttings of Tibouchina pulchra (Cham.) Cogn. (“quaresmeira”). Iheringia, v.58, n.2, p.171-179, 2003.

LANA, R.M.Q. et al. Doses of indolbutyric acid in the rooting and growth of eucalypt cuttings (Eucalyptus urophylla). Bioscience Journal, v.24, n.3, p.13-18, 2008. Available from: $<$ http://www. seer.ufu.br/index.php/biosciencejournal/article/view/6708> Accessed: Aug. 17, 2016.

LEANDRO, R.C.; YUYAMA, K. Rooting of cutia nut cuttings with indolbutiric acid. Acta Amazonica, v.38, n.4, p.597602, 2008. Available from: <http://dx.doi.org/10.1590/S004459672008000400001>. Accessed: Aug. 17, 2016. doi: 10.1590/ S0044-59672008000400001.

LEÃO, P.C.S. Effects of different kinds of cuttings in the scion production grapevine rootstocks, CV. IAC 572 'Jales'. Ciência Rural, v.33, n.1, p.165-168, 2003. Available from: $<$ http://dx.doi. org/10.1590/S0103-84782003000100027>. Accessed: Aug. 17, 2016. doi: 10.1590/S0103-84782003000100027.

LIONAKIS, S.M. Physiological studies of growth and dormancy of the kiwifruit plant (Actinidia chinensis Planch). 1981. 381f. Thesis (Ph.D. Plant Physiology) - University of London.

LOLLI, A.P.O. Influência do ácido indolbutírico no enraizamento de estacas semilenhosas de Lippia alba (Mill.) N.E.Br. In: JORNADA PAULISTA DE PLANTAS MEDICINAIS, 5., 2001, Botucatu, SP. Anais... Botucatu: UNESP, 2001. 112p.

MINDÊLLO NETO, U.R. Herbaceous cutting of peach cv. 'Charme' according to different indolbutyric acid (IBA) and number of leaves. Revista Brasileira de Agrociência, v.12, n.1, p.27-29, 2006. Available from: <http://dx.doi.org/10.18539/cast.v12i1.1296>. Accessed: Aug. 17, 2016. doi: 10.18539/cast.v12i1.1296.

NIENOW, A.A. et al. Rooting of quaresmeira cuttings in two seasons and concentration of indolbutyric acid. Revista Brasileira de Agrociência, v.16, n.1-4, p.139-142, 2010. Available from: $<$ http://www2.ufpel.edu.br/faem/agrociencia/v16n1/artigo19. pdf $>$. Accessed: Aug. 17, 2016.
PAGEL, F.E. Produção de mudas florestais por via assexuada. Santa Rosa: ANORGS, 2004, 37p. (Caderno Didático).

PIO, R. et al. Presence of leaves and apical bud in the rooting of fig tree herbaceous cuttings originating from sprouting. Revista Brasileira de Agrociência, v.10, n.1, p.51-54, 2004. Available from: < http://dx.doi.org/10.18539/cast.v10i1.687> Accessed: Aug. 17, 2016. doi: $10.18539 /$ cast.v10i1.687.

RIBAS, K.C. Interações entre auxinas e co-fatores do enraizamento na promoção do sistema radicular, em estacas de Eucalyptus grandis W. Hill ex Maiden. 1997. 150f. Dissertação (Mestrado em Botânica) - Setor de Ciências Biológicas, Universidade Estadual Paulista, SP.

ROBERTO, S.R. et al. Herbaceous cutting rooting of 'Campinas' (IAC 766) and 'Jales' (IAC 572) vine roostocks on different growth medium. Ciência Rural, v.34, n.5, p.1633-1636, 2004. Available from: <http://dx.doi.org/10.1590/S0103-84782004000500051>. Accessed: aug. 17,2016. doi: 10.1590/S0103-84782004000500051.

RUFINI, J.C.M. et al. Influência da sacarose e do ácido indolbutírico na propagação do maracujazeiro-doce por estaquia. Revista Científica Rural, v.7, n.2, p.122-127, 2002.

SCHEIDT, C. et al. Evidence for the involvement of glutamatergic receptors in the antinociception caused in mice by the sesquiterpene drimanial. Neuropharmacology, v.43, n.3, p.340-347, 2002. Available from: <http://www.sciencedirect.com/science/article/ pii/S002839080200117X>. Accessed: Aug. 17, 2016.

SIMÕES, C.M.O. et al. Plantas da medicina popular no Rio Grande do Sul. Porto Alegre: UFRGS, 1986. 147p.

TRINTA, E.F.; SANTOS, E. Flora ilustrada catarinense. Itajaí: BR Petrobras, 1997. 19p.

XAVIER, A. et al. Rooting of stem and leaf minicuttings in the vegetative propagation of cedro-rosa (Cedrela fissilis Vell.). Revista Árvore, v.27, n.3, p.351-356, 2003. Available from: < http:// dx.doi.org/10.1590/S0100-67622003000300011>. Accessed: Aug. 17, 2016. doi: 10.1590/S0100-67622003000300011. 